\begin{tabular}{|l|l|}
\hline JURNAL ABDI MASYA & Volume 1 Nomor 2 \\
Mei 2021 \\
pp 77-82 \\
Website: https://jurnal.sttw.ac.id/index.php/abma/about \\
E-ISSN : 2774-2849 \\
P-ISSN : 2774-2881
\end{tabular}

\title{
Pembelajaran Cara Cepat Belajar Matematika Di SDN 01 Dan 05 Jepon Kecamatan Jepon Kabupaten Blora
}

\section{LEARNING HOW TO QUICKLY LEARN MATHEMATICS IN SDN 01 AND 05 JEPON, KECAMATAN JEPON, BLORA DISTRICT}

\author{
Anna Mariyani ${ }^{1 *}$, M Iqbal Arrosyad ${ }^{2 *}$, Slamet Utomo ${ }^{3}$, Sumarmi ${ }^{4}$ \\ ${ }^{1}$ (Program Studi Pendidikan Guru Sekolah Dasar STKIP Muhammadiyah Blora) \\ ${ }^{2}$ (Program Studi Pendidikan Guru Sekolah Dasar Universitas Muhammadiyah Bangka Belitung) \\ ${ }^{3}$ (SD N 5 Jepon, Blora) \\ ${ }^{4}$ (SD N 1 Jepon, Blora) \\ *Email: annamariyani@gmail.com, \\ muhammad.iqbalarrosyad@unmuhbabel.ac.id
}

\begin{abstract}
ABSTRAK
Pengabdian ini bertujuan untuk melatih guru SD dalam pembelajaran matematika kepada siswa dengan menggunakan cara cepat belajar Matematika. Metode yang digunakan dalam pengabdian ini yakni pelatihan selama 8 jam dengan materi matematika kelas dasar dengan teknik cepat. Dari hasil pengabdian didapati bahwa dalam mengerjakan soal pretest dan posttest terdapat perbedaan yang signifikan dalam waktu. Pretest rata-rata membutuhkan 1 jam proses pengerjaan 50 soal berhitung sedangkan posttest rata-rata hanya membutuhkan waktu 30 menit pengerjaan. Menjadi fokus bahasan.dapat bersifat generalisasi temuan sesuai permasalahan pengabdian, dapat pula berupa rekomendatif untuk langkah selanjutnya.
\end{abstract}

Kata Kunci : Cara Cepat Belajar, Matematika, pelatihan

\section{ABSTRACT}

This service aims to train elementary teachers in learning mathematics to students by using the fast way to learn mathematics. The method used in this service is 8 hours of training with basic class mathematics material with fast techniques. From the results of the dedication, it was found that in working on the pretest and posttest questions there was a significant difference in time. The pretest on average takes 1 hour to process 50 arithmetic questions, while the posttest average only takes 30 minutes of processing. Being the focus of discussion. It can be the generalization of findings according to community service issues, it can also be in the form of recommendations for the next steps.

Keywords: Fast Learning Method, Mathematics, training

\section{Submit : 9 April 2021 Accepted: 28 April 2021}

\section{Published: 28 Mei 2021}

\section{PENDAHULUAN}

Keberhasilan proses belajar mengajar sangat ditentukan oleh metode pengajaran yang baik, media pembelajaran yang mendukung serta suasana proses belajar yang kondusif. Keterampilan pendidik dalam menumbuhkan motivasi peserta didik juga merupakan salah satu faktor yang mempengaruhi keberhasilan tersebut. Menurut Arrosyad et al.[1], penggunaan media pendidikan secara tepat dapat mengatasi sikap

DOI: https://doi.org/10.52561/abma.v1i2.134 
pasif peserta didik. Secara rinci media pendidikan berguna untuk : 1. Menimbulkan kegairahan belajar. 2. Memungkinkan interaksi yang lebih langsung antara peserta didik dengan lingkungan dan kenyataan. 3. Memungkinkan peserta didik belajar menurut kemampuan dan minatnya [2].

Keterampilan untuk mengadakan variasi juga sangat berpengaruh pada keberhasilan belajar peserta didik. Beberapa manfaat memberikan variasi adalah : 1 . Menimbulkan dan meningkatkan perhatian peserta didik terhadap proses belajar mengajar. 2. Meningkatkan motivasi dan rasa ingin tahu. 3. Membentuk sikap yang positif. 4. Tercipta suasana nyaman dalam belajar dan terhindar dari kebosanan [3]. Mempertimbangkan jumlah siswa usia sekolah Dasar di Kecamatan Jepon yang cukup banyak, dengan pemahaman yang masih kurang dalam pembelajaran matematika, khususnya dalam menggunakan metode-metode yang inovatif dalam pembelajaran matematika, maka Dosen bersama dengan dengan mahasiswa sebagai tim pelaksana memandang perlu untuk mengadakan kegiatan pembelajaran tambahan yang menggunakan metode yang inovatif dengan melibatkan para siswa usia sekolah dasar (SD) di daerah ini, hal ini dikarenakan siswa-siswa didaerah ini membutuhkan penyegaran terkait metode pembelajaran yang selama ini cenderung dituntun untuk menghafal. Agar dapat meningkatkan minat mereka dalam pembelajaran khususnya dalam pembelajaran matematika.

Hasil wawancara dengan beberapa anak usia Sekolah Dasar di Kecamatan Jepon Kabupaten Blora dalam pembelajaran matematika khususnya pada masalah perkalian siswa sering mengalami kesulitan disaat menyelesaikan tugas yang diberikan oleh guru disekolah yang berhubungan dengan masalah perkalian karena siswa merasa kesulitan untuk mengingat jumlah dalam perkalian yang dalam artian banyak siswa Sekolah Dasar yang tidak hapal perkalian dasar 1 sampai 10. Hal ini disebabkan karena pembelajaran yang dilaksanakan selama ini disekolah sangat jarang menggunakan metode-metode yang inovatif pada khususnya. Siswa belajar matematika lebih banyak melalui penjelasan secara langsung oleh guru yang didominasi dengan pemberian ceramah. Hal ini terjadi sebagai akibat dari pemahaman serta keterampilan guru untuk menggunakan metode-metode inovatif dalam pembelajaran matematika juga kurang.

Sebagai akibatnya siswa belajar matematika dengan cara-cara yang kurang bermakna. Siswa cenderung menghafal konsep atau prosedur matematis tertentu [4]. Sehingga mengakibatkan siswa cepat lupa dengan konsep-konsep yang mereka hafal. Secara umum, proses pembelajaran disekolah berlangsung dengan cukup baik, dengan penggunaan media dan metode pengajaran yang belum optimal. Dan sangat diperlukan variasi media dan metode pembelajaran, sehingga proses belajar mengajar dapat meningkat mutunya [5]. Untuk membantu meningkatkan mutu proses belajar mengajar, khususnya dalam bidang matematika, antara lain dengan memberikan variasi media dan metode pembelajaran. Sehingga minat belajar siswa dapat ditingkatkan, terutama dalam mata pelajaran Matematika yang sering dianggap sulit. Kesan ini dapat dikurangi dengan memberikan variasi media dan model pembelajaran yang dapat menarik minat siswa.

Pengabdian masyarakat ini terfokus pada analisis kebutuhan Sekolah Dasar di Blora dalam melakukan proses pendidikan yang lebih baik dari sebelumnya. Pengabdian Masyarakat yang berjudul "Pembelajaran Cara Cepat Belajar Matematika SDN 01 dan 05 Jepon Kecamatan Jepon Kabupaten Blora" ini disusun untuk memenuhi Tri Dharma Perguruan Tinggi STKIP M Blora dengan mitra SDN 01 dan 05 Jepon yang terletak di Koordinator Wilayah Jepon Kabupaten Blora.

Berdasarkan latar belakang di atas, maka dapat terlihat beberapa permasalahan mitra dalam program pengabdian ini yaitu: 1) Kurangnya metode inovatif guru SD dalam pembelajaran matematika kepada siswa; 2) Kurangnya antusias siswa SD dalam mengerjakan soal matematika.

Berdasarkan latar belakang di atas, maka dapat terlihat beberapa permasalahan mitra dalam program pengabdian ini yaitu: 1) Memberikan referensi metode inovatif guru SD dalam pembelajaran matematika kepada siswa; 2) Meningkatkan antusias siswa SD dalam mengerjakan soal matematika. 


\section{METODE}

Adapun metode pelaksanaan kegiatan ini dengan pelatihan kepada guru-guru dengan terbagi dalam beberapa materi. Uraian materi Pembelajaran Cara Cepat Matematika adalah sebagai berikut:

Tabel 3. Uraian Materi Pembelajaran Cara Cepat Matematika

\begin{tabular}{lll}
\hline Sesi & Materi & Uraian Materi \\
\hline 1 & $\begin{array}{l}\text { Soft Opening } \\
\text { Class }\end{array}$ & Pembukaan program pengabdian \\
2 & $\begin{array}{l}\text { Pre Test } \\
\text { Guru/Peserta mengerjakan soal matematika SD }\end{array}$ \\
3 & Preface & $\begin{array}{l}\text { Pengenalan teori tentang konsep pembelajaran matematika di } \\
\text { SD }\end{array}$ \\
4 & Penjumlahan & Trik penjumlahan cepat dengan penerapan akhlaq \\
5 & Pengurangan & Trik pengurangan cepat dengan penerapan akhlaq \\
6 & Perkalian 9 & Trik cepat pengerjaan matematika dalam perkalian 9 \\
7 & Perkalian 11 & Trik cepat pengerjaan matematika dalam perkalian 11 \\
8 & Perkalian 25 & Trik cepat pengerjaan matematika dalam perkalian 25 \\
9 & Perkalian 5 & Trik cepat pengerjaan matematika dalam perkalian 5 \\
10 & Perkalian 11 - & Trik cepat pengerjaan matematika dalam perkalian 11-19 \\
& 19 & Trik cepat pengerjaan matematika dalam persen \\
11 & Persen & Pengulangan materi secara keseluruhan \\
12 & Review & Guru/Peserta mengerjakan soal matematika SD setelah \\
13 & Post Test & mendapat program pengabdian \\
14 & Soft Closing & Penutupan program pengabdian \\
\hline
\end{tabular}

\section{HASIL DAN PEMBAHASAN}

Berdasarkan hasil dan pembahasan pada pengabdian program pembelajaran cara cepat belajar matematika di sdn 01 dan 05 jepon kecamatan jepon kabupaten Blora dapat di jabarkan sebagai berikut:

Adapun beberapa substansi kelayakan mitra dalam melaksanakan program pengabdian masyarakat ini adalah sebagai berikut :

Tabel 1. Subtansi Kelayakan Mitra Program Pengabdian Masyarakat SDN 01 Jepon

\begin{tabular}{lll}
\hline No & $\begin{array}{l}\text { Substansi } \\
\text { Kelayakan }\end{array}$ & Kelayakan Mitra \\
\hline SDN 01 Jepon & \\
\hline $\mathbf{1}$ & Akreditasi & B \\
$\mathbf{2}$ & Kurikulum & Kurikulum 2013 \\
$\mathbf{3}$ & Lokasi & JL. Jatirogo, Jepon, Kec. Jepon, Kab. Blora Prov. Jawa Tengah \\
$\mathbf{4}$ & Jumlah Guru & 3 orang \\
$\mathbf{5}$ & Ruang Kelas & 6 ruang \\
$\mathbf{6}$ & Jumlah & 53 orang \\
& Siswa & \\
\hline
\end{tabular}


Tabel 1. Subtansi Kelayakan Mitra Program Pengabdian Masyarakat SDN 05 Jepon

\begin{tabular}{|c|c|c|c|c|}
\hline No & & & $\begin{array}{l}\text { Substansi } \\
\text { Kelayakan }\end{array}$ & Kelayakan Mitra \\
\hline \multicolumn{5}{|c|}{ SDN 05 Jepon } \\
\hline 1 & & & Akreditasi & B \\
\hline 2 & & & Kurikulum & Kurikulum 2013 \\
\hline 3 & & & Lokasi & $\begin{array}{l}\text { Jl. Raya Blora Cepu Km 06, } \\
\text { Jepon, Kec. Jepon, Kab. } \\
\text { Blora Prov. Jawa Tengah }\end{array}$ \\
\hline 4 & & & Jumlah Guru & 8 orang \\
\hline 5 & & & Ruang Kelas & 6 ruang \\
\hline 6 & $\begin{array}{l}\text { Jumlah } \\
\text { Siswa }\end{array}$ & 168 orang & & \\
\hline
\end{tabular}

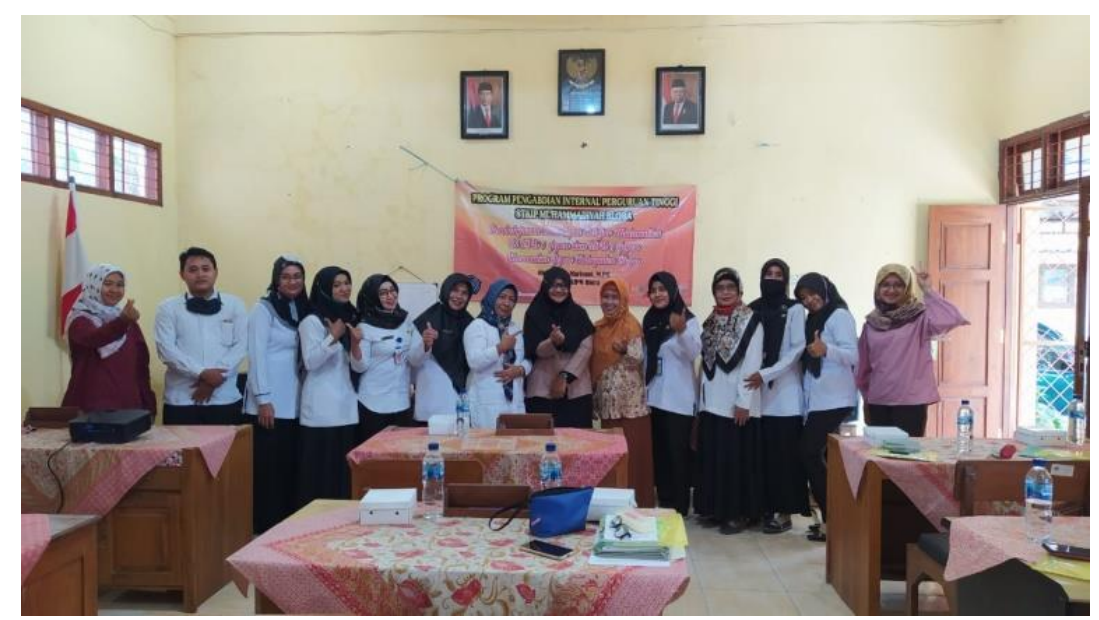

Gambar 1 Foto Bersama Peserta Pengabdian

Data awal diperoleh dari 50 soal pretest yang terdiri dari soal isian yang dikerjakan oleh seluruh peserta kegiatan ini yaitu sekitar 16 peserta. Data akhir diperoleh dari 50 soal posttest yang terdiri dari soal isian yang dikerjakan seluruh peserta kegiatan ini setelah 14 pertemuan selesai. Berdasarkan data awal dan data akhir diperoleh rata-rata pada data awal adalah peserta mengerjakan sekitar 1 jam sedangkan pada posttest peserta dapat mengerjakan selama 30 menit saja. Hal ini berarti penggunaan cara atau trik cepat matematika efektif mempersingkat waktu dan pengerjaan peserta.

Kegiatan pengabdian dilaksanakan dengan urutan kegiatan sebagai berikut:

Tabel 4 Kegiatan Pengabdian

\begin{tabular}{|c|c|c|}
\hline Sesi & Materi & Uraian Materi \\
\hline 1 & $\begin{array}{l}\text { Soft Opening } \\
\text { Class }\end{array}$ & Pembukaan program pengabdian \\
\hline 2 & Pre Test & Guru/Peserta mengerjakan soal matematika SD \\
\hline 3 & Preface & $\begin{array}{l}\text { Pengenalan teori tentang konsep pembelajaran matematika di } \\
\text { SD }\end{array}$ \\
\hline
\end{tabular}




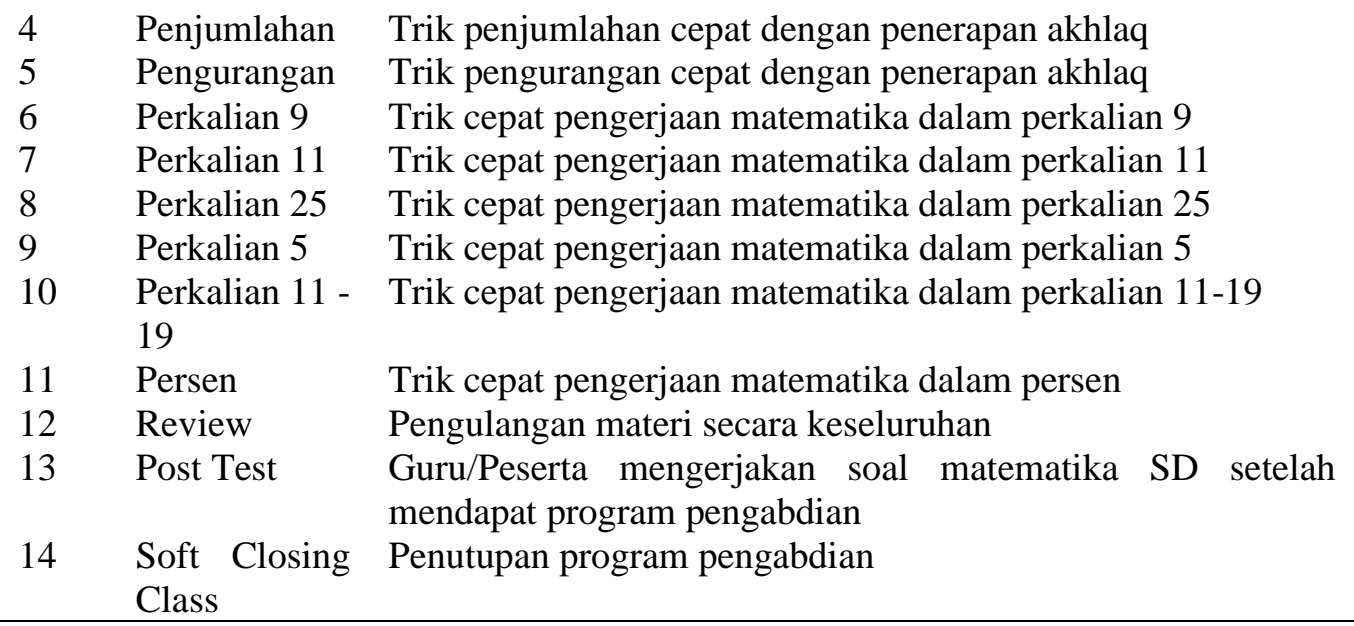

Berdasarkan tabel 4 tentang jadwal kegiatan pengabdian, maka dapat diperjelaskan bahwa pelaksanaan dimulai dengan pembukaan yang di buka langsung oleh pemateri yakni Dosen dari STKIP Muhammadiyah Blora, kegiatan pembukaan dilakukan untuk memulai jalannya kegiatan dan mengenalkan maksud dan tujuan dilaksanakannya pengabdian atau pelatihan ini. Selanjutnya Guru atau peserta mengerjakan latian soal berupa pretest yang bertujuan untuk mengetahui tingkatan pemahaman sebelum dilaksanakannya pelatihan. Selanjutnya diberikan materi tentang trik-trik menghitung cepat dalam mata pelajaran Matematika di SD. Materi yang diberikan diantaranya: Trik penjumlahan cepat dengan penerapan akhlaq, Trik pengurangan cepat dengan penerapan akhlaq, Trik cepat pengerjaan matematika dalam perkalian $9,11,2555,5,11-19$, Trik cepat pengerjaan matematika dalam persen, Pengulangan materi secara keseluruhan, dan Guru/Peserta mengerjakan soal matematika SD setelah mendapat program pengabdian. Setelah itu penutup.

Pelaksanaan pengabdian ini berjalan lancer dari awal pembukaan sampai penutupan. Berdasarkan kegiatan yang dilakssanakan didapati banyak guru yang baru mengetahui triktrik cara menghitung cepat ini. Sehingga selama ini Guru hanya menggunakan cara biasa untuk mengajar. Sehingga dengan adanya pelatihan ini nantinya akan diterapkan dalam proses pembelajarannya. Hal ini juga disampaikan oleh Sukardi [6] bahwa pelatihan dapat menambah wawasan dan pengetahuan bagi peserta yang serius dalam mengikuti [7]. Sehingga manfaat dalam kegiatan ini sangat bias dirasakan oleh guru-guru khususnya yang mengajar mata pelajaran matematika.

\section{KESIMPULAN}

Pada kegiatan pengabdian ini, dapat disimpulkan bahwa trik cepat matematika dapat membantu guru dalam membelajarkan matematika, terlebih dalam materi berhitung perkalian. Siswa SD kelas 2 diharapkan tuntas perkalian 1-10 sehingga dengan adanya kegiatan ini menghasilkan tingkat efektifitas pengerjaan berhitung dibanding dengan cara yang umum digunakan.

Dalam mengerjakan soal pretest dan posttest terdapat perbedaan yang signifikan dalam waktu. Pretest rata-rata membutuhkan 1 jam proses pengerjaan 50 soal berhitung sedangkan posttest rata-rata hanya membutuhkan waktu 30 menit pengerjaan. Menjadi fokus bahasan.dapat bersifat generalisasi temuan sesuai permasalahan pengabdian, dapat pula berupa rekomendatif untuk langkah selanjutny.

\section{UCAPAN TERIMA KASIH}

Peneliti mengucapkan terimakasih kepada pihak kampus STKIP Muhammadiyah Blora yang telah memberikan dana bantuan dalam pelaksanaan pengabdian ini, dan juga ucapan terimakasih kami ucapkan kepada pihak Sekolah Dasar N 1 dan 5 Jepon Blora yang telah mensukseskan kegiatan ini. 


\section{DAFTAR PUSTAKA}

[1] Arrosyad, M. I., Murwaningsih, T., \& Winarni, R. (2017). A study on the development of materials based on local advantage: Improving elementary school students' creativity. International Journal of Research Studies in Education, 7(4), 81-89. https://doi.org/10.5861/ijrse.2017.2000

[2] Meryansumayeka, M., Yusuf, M., \& Suganda, V. A. (2018). Pengembangan Video Pembelajaran Berbasis PMRI untuk Mendukung Mental Calculation Siswa dalam Permasalahan Aritmatika Sosial. Jurnal Elemen, 4(2), 119. https://doi.org/10.29408/jel.v4i2.634

[3] Daik, A. K. V, Daik, A. K. V, Abi, A. M., \& Bien, Y. I. (2020). Analisis gaya belajar matematika pada siswa kelas vii smp negeri oebaki. 2(1), 18-24.

[4] Fredlina, K. Q., Putu, I. G., Juliharta, K., Bagus, I., \& Sudiatmika, K. (2005). PEMBELAJARAN MATEMATIKA DI SEKOLAH DASAR NEGERI 3 MUNDUK. PKM MIFTEK, 42-46.

[5] Muhammad Iqbal, Niswanto, S. I. (2017). Budaya Organisasi Sekolah Dalam Pembentukan Karakter Peserta Didik Pada Sma Negeri 1 Kota Lhokseumawe. Jurnal Administrasi Pendidikan : Program Pascasarjana Unsyiah, 6(4), 234-241.

[6] Sukardi, I. (2016). Character Education Based on Religious Values: an Islamic Perspective. Ta'dib, 21(1), 41. https://doi.org/10.19109/td.v21i1.744

[7] Zedadra, O., Guerrieri, A., Jouandeau, N., Seridi, H., Fortino, G., Spezzano, G., Pradhan-Salike, I., Raj Pokharel, J., The Commissioner of Law, Freni, G., La Loggia, G., Notaro, V., McGuire, T. J., Sjoquist, D. L., Longley, P., Batty, M., Chin, N., McNulty, J., TVERSK, K. A. A., ... Thesis, A. (2019). The Effect of Speed Reading Strategies on Developing Reading Comprehension among the 2nd Secondary Students in English Language. Sustainability (Switzerland), 11(1), 1-14. 